\title{
Effect of Replacing Soybean Concentrate with Bulgur (Wheat Groats) Flour on Quality and Storage Stability of Beef Burger
}

Nadia, A. Abd-El-Aziz' ${ }^{1}$, Amal, M. Abd El-Razek² \& Faten, F. Abdel-salam²

${ }^{1}$ Meat and Fish Technol. Res. Dept., Food Technol. Res. Inst. , Agric. Research Center, ElSabahia, Alexandria, Egypt.

${ }^{2}$ Food Science and Technology Dept., Fac. of Agric., Alexandria Univ., El-Shatby, 21545, Alexandria, Egypt.

\begin{abstract}
Replacing soybean concentrate with Bulgur flour in beef burger manufacture was studied. The results showed that the components of Bulgur were carbohydrate (82.65\%), protein (13.47\%), moisture (11.59\%) and fat (1.8\%). Dietary fiber content was $31.33 \% \mathrm{NDF}$ and $1.98 \%$ ADF. Water absorption, fat absorption and emulsion stability were $173.74 \%, 175.87 \%$ and 39/100g, respectively. Soybean concentrate had high level of isoflavones comparing with Bulgur flour. Genistein , biochanin A, daidzien and formononetin in soybean concentrate were higher 13, 6, 12 and 8 times than that in Bulgur flour. Percentage of DPPH radical scavenging activity in Bulgur and soybean was $28.84 \%$ and $54.42 \%$, respectively. Five different formulations of beef burger were prepared, 3 containing $10 \%, 15 \%$ and $20 \%$ Bulgur flour, one having $20 \%$ soybean concentrate and the last one was $100 \%$ meat . The moisture, protein, fat, ash and carbohydrate contents ranged from 66.37 to $72.72,59.13$ to $70.86,21.48$ to $24.34,3.78$ to 4.81 and 0.17 to $15.48 \%$, respectively in the beef burger samples. Cooking loss and shrinkage increased after 3 months of freezing at $-20^{\circ} \mathrm{C}$, meanwhile decreasing in $\mathrm{WHC}$ was traced. The TBA values of the different burger products and after storage 3 months at $-20^{\circ} \mathrm{C}$ ranged from 0.008 to $0.018 \mathrm{mg}$ malonaldehyde per $1 \mathrm{~kg}$ sample. The TVC ranged from $3.5 \times$ $10^{3}$ to $6.0 \times 10^{4} \mathrm{CFU} / \mathrm{g}$ before and after frozen storage. Enterobacteriaceae was $7.2 \times 10^{2}$ to $5.1 \times 10^{3} \mathrm{CFU} / \mathrm{g}$ in samples at zero time and not detected after one month of storage at $-20^{\circ} \mathrm{C}$. E.coli, Coliform and Staphylococcus aureus were not detected in all samples before and after 3 months of frozen storage. All roasted samples were judged acceptable by the panelists, $10 \%$ and $15 \%$ beef burger with Bulgur had the highest acceptability.
\end{abstract}

Key words: Bulgur, soybean, beef burger, isoflavonesd.

\section{INTRODUCTION}

Meat plays a pivotal role in alleviating malnutrition due to its content of high quality protein, vitamins, minerals and fat (Mallika et al., 2009). The main problem of meat and meat products is the perishability due to their very low inherent antioxidant capacity (Gupta \& Savalia, 2012). The antioxidants prevent fat oxidation, reduce the harmful free radicals and protect cells from damage. (Ruban et al., 2009) .The antioxidant capacity of meat and meat products can be improved by natural antioxidants such as flavonoids present in different plant sources such as legumes, cereal, vegetables, fruits and their industrial by-products (Hue et al., 2011). These materials are also rich in dietary fibers. Therefore, the incorporation of such sources at suitable levels enhances the cooking yield, emulsion stability and functional value of meat products. (Perumalla et al., 2011).
Flavonoids are phenolic compounds having antioxidants and chelating properties. They form from three major classes, flavones (such as, quercetin and rutins), isoflavonoids (such as, genistein, glycitein, daidzein, formononetin) and neoflavonoids (Tapas et al., 2008). The antioxidant activity of these compounds is mainly due to high reactivity of their hydroxyl groups. The recommended dietary allowance of flavonoids is not fixed (Kumar et al., 2013). The USDA (2011) stated that for getting the therapeutic and health promoting benefits ,a minimum 50-500 mg of flavonoid per day are recommended. Acidity and processing of food (boiling and cooking) may cause up to $50 \%$ destruction of flavonoids (kumar et al., 2013). In India, the average daily intake of flavonols is about $1-2 \mathrm{~g}$ per day out of which the mean intake of flavonols and flavones accounts about $23 \mathrm{mg}$ /day and quercetin about $16 \mathrm{mg} /$ day. For rat, the $\mathrm{LD}_{50}$ is $2-10 \mathrm{~g}$ per animal for most flavonoides. Such level is unrealis- 
tic in normal diet (Sandhar et al., 2011). Kumar et al. (2013) suggested daily intake of less than $1 \mathrm{mg}$ of flavonoids per adult per day for human- being. Generally excess intake of flavonoids causes diarrnoea due to problem in digestion.

Beef burger is one of the meat popular product overall the world. The meat manufacturers continually try to improve processing quality, storage stability, safety, sensory attributes, nutritive value and functionality of their products. Such properties can be achieved by replacing part of meat by some types of plant sources rich in phenolic compounds such as flavonoids and dietary fibers. Soybean is one such sources. It is rich in isoflavones, a one class of flavonoids. It was used as meat replacer during preparing beef burger .Soybean flavonoids have some health benefits such as protection against breast and prostate cancers, heart disease and osteoporosis (Hendrich et al. 1994) .Recently, the similarity between chemical composition of isoflavones and esterogen hormone causes controversy about the consumption and utilization of soybean in food production (Kumar et al., 2013). Also, isoflavones devoid of reactive hydroxyl groups and sequentially showed little antioxidant activity. According to Cai et al. (2006), the antioxidant capacity of flavonoids having the following order as flavanols $>$ flavonols $>$ chalcones $>$ flavones $>$ isoflavone.

Bulgur (wheat groats) is rich in dietary fibers, vitamin $\mathrm{B}_{1}, \mathrm{~B}_{2}$ and phenolic compounds .Generally Bulgur is a staple for centuries in many Middle and Near Eastern countries due to its low cost, long storability, simple processing, high nutritional value (Köksel et al., 1999) and health protection effect against cardiovascular and heart diseases (Ozvural \& Vural , 2008). Bulgur is commercially manufactured from soaked, blanched, gelatinized and dried durum wheat grains (Bayram, 2007).

Therefore the present study is aimed to replace soybean concentrate with Bulgur flour in beef burger manufacture. The influence of such replacement on quality and storage stability of this product was investigated.

\section{MATERIALS AND METHODS}

\section{Materials}

Brazial frozen imported back rip boneless beef, beef tallow ,fresh onion, refined fine iodized common salt, spices blend mixture of National Co., corn oil, Bulgur (wheat groats) of Al Suhagy for Food Industries, soybean concentrate of Bakri Packing Co., grease-proof paper, polyethylene bags and foam plates $(22 \times 17 \mathrm{~cm})$ were purchased from Alexandria local market, Egypt.

The following standards isoflavone : genistein (4',5,7, trihydroxy isoflavone), daidzein $\left(4^{\prime}, 7\right.$, dihydroxyisoflavone), formononetin (7-hydroxy -4'- methoxyisoflavone) and biochanin A (5,7-dihydroxy -4-methoxy isoflavone) were obtained from Sigma -Aldrich, USA. All solvents used in extraction and determination were of high -purity "HPLC" grade (Merck, Darmstadt, Germany), other reagents and chemicals were analytical grades.

\section{Methods}

\section{Technological methods:}

Beef burger preparation:- Frozen meat was thawed at room temperature $\left(22 \pm 3^{\circ} \mathrm{C}\right)$ for $4-5 \mathrm{hr}$, dressed by removing their surrounded fat layers, cut into $10 \mathrm{~cm}$ thickness portions then mixed with beef tallow at 9:1 (w/w) ratio and minced 2 times through $5 \mathrm{~mm}$ plate of Luska meat chopper .To the resultant minced meat , $4 \%$ of small pieces of fresh onions, $1 \%$ salt, $1 \%$ spices mixture, and $20 \%$ cold water were added and well mixed. Five different formulations of beef burger were prepared, 3 containing $10 \%, 15 \%$ and 20\% Bulgur flour ,one having $20 \%$ soybean concentrate and the last one was $100 \%$ meat as the control. Each formula was chopped 2 times using Luska chopper, formed into around pieces with $10 \mathrm{~cm}$ diameter, $1 \mathrm{~cm}$ thickness and $70 \mathrm{~g}$ weight. Each piece was surrounded with 2 pieces of grease-proof paper, then packed in polyethylene bags. The bags were kept at $-20^{\circ} \mathrm{C}$ in deep freezer (Aristone) for 3 months.

Cooking of beef burger :- Raw burger samples were roasted in roasting pan at $140^{\circ} \mathrm{C}$ until center temperature reached $80^{\circ} \mathrm{C}$, then cooled to room temperature $\left(22 \pm 3^{\circ} \mathrm{C}\right)$. The cooking loss and shrinkage were calculated using the following equations as mentioned by El-Magoli et al. (1996).

Cooking loss $(\%)=\frac{\mathrm{w}_{1}-\mathrm{w}_{2} \times 100}{\mathrm{w}_{1}}$

Where:-

$\mathrm{W}_{1}$ : weight of beef burger sample before cooking. $\mathrm{W}_{2}$ : weight of beef burger sample after cooking. 
Shrinkage $(\%)=\frac{A_{1}-A_{2} \times 100}{A_{1}}$

Where:

$A_{1}=$ area of burger sample before cooking.

$\mathrm{A}_{2}=$ area of burger sample after cooking.

\section{Analytical method:-}

\section{Physical properties:-}

Water holding capacity (WHC) of beef burger was determined using filter paper press method (Aman, 1983).Water and fat absorption of Bulgur flour were determined according to Del Rosario \& Flores (1981) using distilled water and corn oil ,respectively. The emulsion capacity was estimated by formation suspension of Bulgur flour, distilled water and corn oil, then homogenized ,heated at $80^{\circ} \mathrm{C}$,cooled and centrifuged as stated by Chau \& Cheung(1998).

The colour values, lightness $\left(\mathrm{L}^{*}\right)$, redness $\left(\mathrm{a}^{*}\right)$ and yellowness $\left(\mathrm{b}^{*}\right)$ of burger samples were evaluated using a Hunter Lab Ultra Scan VIS model, colorimeter (USA). The instrument was standardized during each sample measurement with a black and white tail $\left(\mathrm{L}^{*}=94.1, \mathrm{a}^{*}=1.12, \mathrm{~b}^{*}=1.26\right)$. Five reading of each colour index of Hunter scale $\left(\mathrm{L}^{*}\right.$, $a^{*}, b^{*}$ ) were recorded (Santipanichwing \& Suphantharika,2007).

Texture properties were analyzed by texture profile analysis (TPA) in a TA-XT plus Texture Analyzer (Texture Pro CT3 V1.2,Brookfield, Middleboro, USA) as described by Yuan \& Chang (2007) .Burger section (height-20 mm) were axially compressed to $40 \%$ of their original height. Force time deformation was obtained with $10 \mathrm{~kg}$ load cell, applied at a cross head speed of $1 \mathrm{~mm} / \mathrm{s}$. Attributes calculated were hardness, cohesiveness, and chewiness.

\section{Chemical analysis:-}

Proximate composition : Moisture, protein, fat and ash contents of beef burger and Bulgur flour were determined according to the AOAC (2000) carbohydrate content was calculated by difference .Thiobarbituric acid (TBA) was calorimetrically estimated according to Park et al. (2007) using UVVIS Spectrophotometer Laxo alpha 1102, suit and expressed as mg malonaldehyde per kilogram fat or sample. Dietary fibers were determined according to the method of AOAC (1990). The pH was determined using $\mathrm{pH}$ meter type MVX100 Beckman
(USA) at room temperature $\left(22 \pm 3^{\circ} \mathrm{C}\right)$ as described in AOAC (2000).

\section{Isoflavones identification by HPLC:-}

Separation, identification and determination of Bulgur flour and soybean concentrate isoflavones were carried out as follow: Extraction of isoflavones was done as described by Wang \& Murphy (1994) by stirring $2 \mathrm{~g}$ of sample with $10 \mathrm{ml}$ of acetonitrile and $2 \mathrm{ml}$ of $0.1 \mathrm{~N} \mathrm{HCL}$ in $125 \mathrm{ml}$ screw tap Erlenmeyer flask for $2 \mathrm{hr}$ at room temperature. After filtration through Whatman No .42 filter paper, the filtrate was dried on a rotary evaporator at $30^{\circ} \mathrm{C}$. The dried material was redissolved in $10 \mathrm{ml}$ of $80 \%$ HPLC grade $\mathrm{MeOH}$ in water. Aliquot of sample was filtered through a $0.45 \mu \mathrm{m}$ poly tetrafluoro ethylene (PTFE) filter unit and analyzed by HPLC according to Frank et al. (1994) with slight modification.A unit of HPLC (Shinaezu, Japan) connected with a UV-VIS diode-array detector (Dionex -Ulti Mate 3000) and with a reversed -phase C18 (ODS) column (250x4.5 mm. Dionex - Ulti Mate 3000) was used. A volume of $25 \mu 1$ sample or standards was injected at column temperature setting at $35^{\circ} \mathrm{C}$. Isoflavones were separated with two mobile phases: phase A $(0.1 \%$ glacial acetic acid in water $)$ and phase $\mathrm{B}(0.1 \%$ glacial acetic acid in acetonitrile ).The gradient profile was: $20 \% \mathrm{~A}-45 \%$ $\mathrm{B}$ in 20 min., $45 \% \mathrm{~A}-100 \% \mathrm{~B}$ in $1 \mathrm{~min} ., 100 \% \mathrm{~B}$ for $4.5 \mathrm{~min} ., 100 \% \mathrm{~B}-20 \% \mathrm{~A}$ in $0.5 \mathrm{~min}$. The flow rate was set at $0.7 \mathrm{ml} / \mathrm{min}$. UV spectra were recorded (from 200 to $350 \mathrm{~nm}$ ) and area responses were integrated by water PDA software. The total processing time was $20 \mathrm{~min}$. The peaks of the separated isoflavones were compared with those of standard isoflavones (genistein $\left(4^{\prime}, 5,7\right.$, trihydroxyisoflavone), daidzein (4',7,dihydroxy isoflavone), formononetin (7-hydroxy-4'- methoxyisoflavone) and biochanin A (5,7-dihydroxy -4'-methoxyisoflavone). The concentration of isoflavones in the samples was calculated in terms of $\mathrm{mg} / \mathrm{g}$ dry matter.

\section{Antioxidant activity:-}

Radical scavenging activity of Bulgur flour and soybean concentrate extracts was measured using the stable radical DPPH (2,2 diphenyl-1-picrylhydrazyl ) according to Brand -Williams et al .(1995). The percentage of DPPH scavenging for extracts was calculated as follows:-

Radical Scavenging activity $\%=$

$$
\left[\left(\mathrm{A}_{\text {Control }}-\mathrm{A}_{\text {Sample }}\right) / \mathrm{A}_{\text {Control }}\right] \times 100
$$


Microbiological methods: Ten grams of beef burger were blended with $90 \mathrm{ml}$ of sterilized peptone water for $2 \mathrm{~min}$, in sterilized glass jar of blender. Appropriate dilution was prepared for enumeration using standard microbiological pour plate technique and the recommended culture media of Oxiod (2002). Plate count agar medium was used for enumerating the Total Viable Count (TVC), after incubating at $35-37^{\circ} \mathrm{C}$ for $48 \mathrm{hr}$ Violet red bile agar with methyl umberliferyl glucourniod (VRBMUG) selective media was used to isolate coliform, gram negative enteric bacteria and rapid detection of E.coli. The proper dilution of the beef burger homogenate was inoculated in steril petri dishes then medium was poured and plates were incubated at $37^{\circ} \mathrm{C}$.for $18-24 \mathrm{hr}$ Colonies of lactose negative enterobacteriaceae are colourless and those of lactose positive are red and often surround by a forbid zone due to precipitation of bile acid are coliform, light blue fluorescent colonies under UV-lamp (336 nm.) denote as E.coli. The recommended Difico Baried Parker agar medium by ICMSF (1978) was used to detect Staphylococcus aureus after incubating the plates at $35-37{ }^{\circ} \mathrm{C}$ for $48 \mathrm{hr}$ the black shiny colonies with narrow white margin and surrounded by clear zones were counted as Staphylococcus aureus.

Sensory Evaluation : - Colour ,texture, ,taste, odour and overall acceptability of cooked beef burger were organoleptically evaluated using 10 trained panelists from, Food Science and Technology Department, Faculty of Agriculture, Alexandria University. They were asked to rate their acceptabilities of cooked burgers products according to nine point scale, ranging from the like extreme 9 to dislike extreme 1 point as described by Meilgaard et al .(1999).

Statistical Analysis:- Statistical analysis system (SAS) software 917 SAS (USA,2003) using two- way analysis of variance (ANOVA) was followed. The differences among means were determined for significance at $P<0.05$ using Duncan's multiple range test.

\section{RESULTS AND DISCUSSION}

Proximate composition, dietary fibers and functional properties of Bulgur flour: - According to the data in Table (1) the higher component of Bulgur is carbohydrate $(82.65 \%)$, while fat was the lowest (1.8\%). Bulgur has a considerable amount of protein $(13.74 \%)$ consisted of balance of amino acids (Wijngaard \& Arendt, 2006). The results of
Köksel et al.(1999) showed that protein and ash contents of Bulgur ranged from $9.5 \%$ to $11.4 \%$ and from $1.2 \%$ to $1.95 \%$, respectively. Drying process of Bulgur can be done naturally or in towers to lower Bulgur moisture content to $\sim 12 \%$ (Bayram, 2007).In the present study, moisture content of Bulgur was $11.59 \%$.

Comparing with soybean protein concentrate, Bulgur had higher amount of carbohydrate $(82.65 \%)$ and relatively high in fat. Wang \&Murphy (1994) reported that protein, ash, fat and carbohydrate contents of soybean concentrate were $60 \%$, $5 \%, 1 \%$ and $6 \%$,respectively.

The results in Table (1) show that Bulgur contained high values of the following types of dietary fibers; neutral detergent fiber (NDA) $31.33 \%$, acid detergent fiber (ADF) $1.98 \%$, hemicellulose $(29.35 \%)$, cellulose $(1.48 \%)$, and lignin $(0.5 \%)$. These types of fibers are important elements in the human diet. They represent the unhydrolyzed plant storage and cell wall polysaccharides by human digestive enzymes (Bethesda, 1986). Moreover Yang et al. (2014) found that the total dietary fiber of Bulgur was $26 \%$. This amount lies in the range of recommended amount by the American Diabetes Association in 1994 (25-35 g of dietary fiber per day) for persons suffering from diabetes and also in that suggested by the Cancer Institute in 1986 (20-35g /day) in US diet (National Cancer Institute, 1984).It has an immense effect on disease prevention and health maintenance, in addition to certain dietary fiber could act as a hypocholestrolemic factor (Wells \& Ershoff, 1961).

Some function properties of Bulgur flour were determined and the results in Table (1) show that Bulgur had water absorption of $173.74 \%$, fat absorption $175.87 \%$ and $39.0 \mathrm{ml}$ oil $/ 100 \mathrm{~g}$ as emulsion stability. Determination of such properties helps in estimating the proper added quantity of dry Bulgur flour after hydration to replace minced meat in preparing some types of meat products. Generally, the functional properties of Bulgur flour are closely related to its content, compassion, presence, absence and availability of both hydrophilic and hydrophobic groups in its molecules. Also, its content of fat and fibers play a role in reducing and increasing such properties. Fat constrains water absorption while fibers encourage the holding capacity of water especially the soluble ones such as pectin and gums than cellulose fibers (Borderias et al., 2005). Notwithstanding, the capacity of fiber 
Table 1: Proximate chemical composition, dietary fibers and some functional properties of Bulgur flour

\begin{tabular}{ll}
\hline \multicolumn{1}{c}{ Determination } & Value* \\
\hline 1- Proximate composition (on dry weight basis\% ) & \\
Moisture & $11.59 \pm 0.010$ \\
Crude fat & $1.80 \pm 0.05$ \\
Crude protein & $13.74 \pm 0.09$ \\
Ash & $1.81 \pm 0.05$ \\
Carbohydrate** & $82.65 \pm 0.01$ \\
2- Dietary fibers (\%) & \\
Neutral detergent fiber (NDF) & $31.33 \pm 0.05$ \\
Acid detergent fiber (ADF) & $1.98 \pm 0.04$ \\
Hemicellulose & $29.35 \pm 0.04$ \\
Cellulose & $1.48 \pm 0.03$ \\
Lignin & $0.5 \pm 0.01$ \\
3- Functional properties & \\
Water absorption (\%) & $173.74 \pm 0.020$ \\
Fat absorption (\%) & $175.87 \pm 0.019$ \\
Emulsion stability (ml oil / 100g) & $39.0 \pm 0.15$ \\
\hline
\end{tabular}

* Mean \pm S.D. $\quad * *$ Calculated by difference.

to bind fat depends more on its porosity than on its molecular affinity.

Isoflavone and antioxidant activity of $\mathrm{Bul}$ gur flour and soybean concentrate: The results in Table (2) show the HPLC separation, identification and content of isoflavones of Bulgur flour and soybean concentrate. The following isoflavones compounds were identified in Bulgur and soybean; genistein, biochanin A, diadzien and formononetin. The results indicated that soybean concentrate had high level of the different isoflavones comparing with Bulgur flour. Genistein, biochanin A, daidzien and formononetin in soybean concentrate were found to be more than 13, 6, 12 and 8 times than that in Bulgur flour. Wang \& Murphy (1994) stated that isoflavones are one class of phytochemical compounds and found in large amounts in soybean. The major isoflavones in soybean are isoflavone aglycons, genistein and diadzein. Hendrich et al. (1994) reported that soybean is one of rich sources of isoflavones. Recently Kumar et al. (2013) mentioned that there is an argument about use of soybean in food production due to the similarity between chemical composition of its isoflavones and esterogen hormone.

Percentage of DPPH radical scavenging activity in both Bulgur flour and soybean concentrate was $28.84 \%$ and $54.42 \%$, respectively as shown in Table (2) .This means that this characteristic in Bulgur was nearly half of soybean concentrate .This may be attributed to conditions of preparing Bulgur which include severe heat treatment during gelatinization and drying of durum wheat comparing with these followed during soybean concentrate production including, solvent extraction and drying. Pratte \& Birac (1979) found that soybeans, defatted soy flour, soy protein concentrates and soy isolate have appreciable antioxidant activity as detected by the rate of $\beta$-carotene bleaching in lipid -aqueous system. This was due to their content of phenolic compounds. According to Giambanelli et al. (2018), the antioxidant activity differed among durum wheat species. The whole einkon wheat had the highest antioxidant activity and the American whole emmer wheat had the lowest activity. According to Kumar et al. (2013) the antioxidant activity is mainly due to the phenolic compounds in the wheat grains such as flavonoids and the high reactivity of their hydroxyl groups. Acidity and processing such as boiling and cooking may cause up to $50 \%$ destruction in such compounds.

\section{Beef burger characteristics and frozen stor- age stability}

Proximate composition: The data in Table (3) show that the moisture, protein, fat, ash and carbohydrate contents ranged from 66.37 to 72.72 , 59.13 to $70.86,21.48$ to $24.34,3.78$ to 4.81 and 0 . 17 to $15.48 \%$, respectively for the different types of the prepared beef burger investigated here. The highest significant $(P<0.05)$ value of moisture, protein, fat, and ash contents were found in $100 \%$ meat beef burger and the lowest in the product containing 20\% Bulgur flour. No significance $(P<0.05)$

Table 2: Isoflavones components and percentage of DPPH radical scavenging activity of Bulgur flour and soybean concentrate

\begin{tabular}{lccccc}
\hline \multirow{2}{*}{ Material } & \multicolumn{4}{c}{ Isoflavones compounds as mg/g } & DPPH radical scavenging \\
\cline { 2 - 5 } & Genistein & Biochanin A & Daidzein & Formononetin & activity (\%) \\
\hline Bulgur & 0.0044 & 2.3735 & 1.1556 & 0.05408 & 28.84 \\
Soybean & 0.0554 & 13.4539 & 13.8053 & 0.4100 & 54.42 \\
\hline
\end{tabular}


Table 3: Proximate chemical composition of beef burger samples (On dry weight basis).

\begin{tabular}{lccccc}
\hline & \multicolumn{4}{c}{ Type of beef burger } \\
\cline { 2 - 6 } Component (\%) & Meat 100\% & $\begin{array}{c}\text { Soybean } \\
\text { concentrate } \mathbf{2 0 \%}\end{array}$ & $\mathbf{1 0 \%}$ & $\mathbf{1 5 \%}$ & $\mathbf{2 0 \%}$ \\
\cline { 2 - 6 } & $72.2^{\mathrm{a}}$ & $67.72^{\mathrm{b}}$ & $68.83^{\mathrm{b}}$ & $67.84^{\mathrm{b}}$ & $66.37^{\mathrm{c}}$ \\
Moisture & $70.86^{\mathrm{a}}$ & $66.34^{\mathrm{b}}$ & $65.01^{\mathrm{b}}$ & $62.09^{\mathrm{c}}$ & $59.13^{\mathrm{d}}$ \\
Crude protein & $24.34^{\mathrm{a}}$ & $21.48^{\mathrm{b}}$ & $22.98^{\mathrm{ab}}$ & $22.30^{\mathrm{ab}}$ & $21.61^{\mathrm{b}}$ \\
Crude fat & $4.63^{\mathrm{ab}}$ & $4.81^{\mathrm{a}}$ & $4.06^{\mathrm{ab}}$ & $3.92^{\mathrm{b}}$ & $3.78^{\mathrm{b}}$ \\
Ash & $0.17^{\mathrm{d}}$ & $7.37^{\mathrm{c}}$ & $7.95^{\mathrm{c}}$ & $11.69^{\mathrm{b}}$ & $15.48^{\mathrm{a}}$ \\
\hline
\end{tabular}

*Carbohydrate was calculated by differences.

Means in a row with the same letter are insignificantly different at $P<0.05$ level.

variations were traced in proximate composition between beef burgers containing 20\% soybean concentrate and that with $10 \%$ Bulgur flour .Generally, replacing meat with Bulgur flour and soybean concentrate resulted in increase in carbohydrate content and reduction in other proximate composition components. Such changes were more noticeable with elevating the replacing meat level. This difference between soybean and Bulgur burger resulted from the difference in their chemical composition and the ratio of their incorporation.
Small differences were observed in the calculation of caloric value (kcal. $\left.100 \mathrm{~g}^{-1}\right)$ of these beef burger products. The burger (100\% meat) was the highest in this value ( 503.18 ) followed by those contained 10\% Bulgur (498.66), 15\% Bulgur (495.82), 20\% Bulgur ( 492.93) and lastly that having $20 \%$ soybean concentrate (488.16) .

Cooking loss, shrinkage and water holding capacity (WHC):- The data in Table (4) show significant $(P<0.05)$ increase in cooking loss, shrinkage, and reduction in WHC of the prepared beef

Table 4: Cooking loss, shrinkage and water holding capacity (WHC) of beef burger samples after storage at $-\mathbf{2 0}^{\circ} \mathrm{C}$ for 3 months.

\begin{tabular}{llccc}
\hline \multirow{2}{*}{ Property } & Type of burger & Storage time at-20 ${ }^{\circ} \mathbf{C}(\mathbf{m o n t h})$ & \multirow{2}{*}{ Mean } \\
\cline { 3 - 4 } & & $\mathbf{0}$ & $\mathbf{3}$ & \\
\hline Cooking loss & $100 \%$ Meat & 22.96 & 29.90 & $26.43^{\mathrm{a}}$ \\
& $20 \%$ Soybean concentrate & 13.57 & 17.01 & $15.29^{\mathrm{c}}$ \\
& $10 \%$ Bulgur & 20.18 & 24.42 & $22.32^{\mathrm{b}}$ \\
& $15 \%$ Bulgur & 19.36 & 24.20 & $21.78^{\mathrm{b}}$ \\
& $20 \%$ Bulgur & 12.69 & 15.95 & $14.32^{\mathrm{c}}$ \\
\hline Mean & & $17.75^{\mathrm{b}}$ & $22.29^{\mathrm{a}}$ & \\
\hline Shrinkage & $100 \%$ Meat & 40.82 & 45.75 & $43.28^{\mathrm{a}}$ \\
& $20 \%$ Soybean concentrate & 22.83 & 26.49 & $24.66^{\mathrm{c}}$ \\
& $10 \%$ Bulgur & 23.43 & 31.79 & $27.61^{\mathrm{b}}$ \\
& $15 \%$ Bulgur & 21.80 & 29.10 & $25.45^{\mathrm{c}}$ \\
& $20 \%$ Bulgur & 18.60 & 28.74 & $23.66^{\mathrm{c}}$ \\
\hline Mean & & $25.49^{\mathrm{b}}$ & $32.37^{\mathrm{a}}$ & \\
\hline Water holding capacity (WHC \%) & $100 \%$ Meat & 62.22 & 60.19 & $61.20^{\mathrm{b}}$ \\
& $20 \%$ Soybean concentrate & 67.70 & 65.82 & $66.76^{\mathrm{a}}$ \\
& $10 \%$ Bulgur & 68.62 & 64.47 & $66.54^{\mathrm{a}}$ \\
& $15 \%$ Bulgur & 68.34 & 64.57 & $66.45^{\mathrm{a}}$ \\
& $20 \%$ Bulgur & 68.12 & 64.71 & $66.41^{\mathrm{a}}$ \\
\hline Mean & & $67.00^{\mathrm{a}}$ & $63.95^{\mathrm{b}}$ & \\
\hline
\end{tabular}

Means with the same letter are insignificantly different at $P<0.05$ level. 
burger types after 3 months of storage at $-20^{\circ} \mathrm{C}$. Such changes were significantly $(P<0.05)$ more in burger (contained 100\% meat) and reduced with rise of plant meat replacer in the prepared beef burger types. No significant changes were observed between the two products containing $20 \%$ soybean concentrate and 20\% Bulgur flour.

McDonagh et al. (2005) reported that normal fat beef burger had lower WHC and higher cooking loss. Shrinkage and cooking loss were found to increase during frozen storage due to muscle protein denaturation and release of water and fat. These are the main causes behind the reducing in piece diameter (shrinkage), WHC and cooking loss of burger. Plant meat substitutes reduced such losses by increasing binding forces between water and oil in this product. The reduction in cooking loss, WHC and shrinkage was observed with increase the proportion of plant meat replacer to $20 \%$.Carbohydrate, especially fibers in Bulgur, protein and ash in soybean concentrate may be responsible for that (Hayes et al., 2009). Pintado et al. (2016) showed that cooking loss, shrinkage and WHC loss were lower in beef burger substituted with soybean flour, concentrate and isolate than the product free from such substitutes.

Colour, texture, $\mathrm{pH}$ and Thiobarbituric acid (TBA): The results in Table (5) show the changes in colour, texture, $\mathrm{pH}$ and TBA in beef burger samples at zero time and after 3 months of storage at $-20^{\circ} \mathrm{C}$.

Colour parameter: Substitution of meat by either Bulgur flour and /or soybean concentrate in preparing beef burger caused reduction in its fat and protein content (Table 3 ) and sequentially affected the colour parameters. Both lightness $\left(\mathrm{L}^{*}\right)$ and yellowness $\left(b^{*}\right)$ increased while the redness $\left(a^{*}\right)$ of beef burger samples decreased due to plant substitution process. Relatively, changes in the aforementioned colour parameters were observed either for the type of plant substitutes, Bulgur and soybean concentrate, or for the ratio of meat replacer, in case of Bulgur. Storage at $-20^{\circ} \mathrm{C}$ for 3 months caused an increase in lightness and relatively changes in redness $\left(\mathrm{a}^{*}\right)$ and yellowness $\left(\mathrm{b}^{*}\right)$ of beef burger samples containing plant replacer either Bulgur or soybean. Such changes were observed in burger containing $100 \%$ meat. Generally, frozen storage had little effect on the colour parameter of beef burger (Pintado et al. 2016).
Texture profile analysis : Texture properties were affected by substitution of meat with plant materials, Bulgur flour and soybean concentrate along with the frozen storage at $-20^{\circ} \mathrm{C}$ for 3 months. As shown from Table (3), the burger (100\% meat), rich in protein and fat than other products. This type of burgers, had the highest hardness before and after frozen storage (Table 5), comparing with the other burger products. This means that reduction in both fat and protein reduced the product hardness. This was confirmed when comparing the hardness of burger containing soybean concentrate with that containing Bulgur flour. The former contains high protein, fat and ash than Bulgur products. Fiber or carbohydrate in Bulgur may play a role in improving texture properties by increasing the emulsification stability and gelling properties of the Bulgur protein. Before frozen storage, the burger $(100 \%$ meat), had higher cohesiveness than other's burger products containing plant meat substitutes. After 3 months of storage at $-20^{\circ} \mathrm{C}$, the carbohydrate or fibers in Bulgur burgers may be responsible for the increasing of their cohesiveness and chewiness.

The pH and TBA changes:- The results in Table (5) show that $\mathrm{pH}$ values ,ranged between 5.8 to 6.17 and 6.02 to 6.07 in different beef burger types before and after frozen storage for 3 months. These values were within the normal limits for the products of this kind. This means that the $\mathrm{pH}$ values of these products did not influence neither by type nor by the ratio of added plant meat replacer as well as frozen storage.

The TBA values of the different burger products before and after storage for 3 months at $-20^{\circ} \mathrm{C}$ ranged from 0.008 to $0.018 \mathrm{mg}$ malonaldehyde per1 $\mathrm{kg}$ sample. These values were below the level of incipient rancidity ( $\geq 1)$ (Ockerman, 1976). The low TBA values of different types of beef burger samples reported here, either free or containing Bulgur flour and soybean concentrate, before and after frozen storage, suggest that these products are viable in terms of oxidative stability.

Microbiological quality :- The Total Viable Count (TVC), Enterobacteriaceae, E.coli, Coliform and Staphylococcus aureus were determined in beef burger products during storage at $-20^{\circ} \mathrm{C}$ for 3 months. The results in Table (6) show that TVC ranged from $3.5 \times 10^{3}$ to $6.0 \times 10^{4} \mathrm{CFU} / \mathrm{g}$ in different burger products before and after frozen storage. Freezing temperature caused decreasing in the count of TVC in all samples. Generally this 
Table 5 : Colour, texture, $\mathrm{pH}$ and TBA of beef burger samples after storage at $-20^{\circ} \mathrm{C}$ for 3 months

\begin{tabular}{|c|c|c|c|c|c|c|c|c|c|c|}
\hline \multirow{3}{*}{$\begin{array}{c}\text { Type of burger } \\
\text { Storage time at }-20^{\circ} \mathrm{C}(\text { month })\end{array}$} & \multirow{2}{*}{\multicolumn{2}{|c|}{$100 \%$ Meat }} & \multirow{2}{*}{\multicolumn{2}{|c|}{$\begin{array}{l}20 \% \text { soybean } \\
\text { concentrate }\end{array}$}} & \multicolumn{6}{|c|}{ Bulgur } \\
\hline & & & & & \multicolumn{2}{|c|}{$10 \%$} & \multicolumn{2}{|c|}{$15 \%$} & \multicolumn{2}{|c|}{$20 \%$} \\
\hline & $\mathbf{0}$ & 3 & $\mathbf{0}$ & 3 & 0 & 3 & $\mathbf{0}$ & 3 & $\mathbf{0}$ & 3 \\
\hline \multicolumn{11}{|l|}{ Property } \\
\hline \multicolumn{11}{|l|}{ Colour units } \\
\hline Lightness (L*) & 39.88 & 45.38 & 43.66 & 47.71 & 43.92 & 47.90 & 44.02 & 49.35 & 44.78 & 50.80 \\
\hline Redness (a*) & 6.46 & 4.39 & 5.73 & 5.42 & 5.15 & 4.14 & 5.34 & 4.16 & 5.96 & 4.33 \\
\hline Yellowness $\left(b^{*}\right)$ & 14.93 & 14.39 & 16.39 & 14.66 & 16.89 & 14.96 & 16.84 & 14.14 & 16.88 & 14.40 \\
\hline \multicolumn{11}{|l|}{ Texture profile analysis (TPA) } \\
\hline Hardness (g) & 300 & 1465 & 294 & 869 & 283 & 893 & 262 & 905 & 252 & 921 \\
\hline Cohesiveness & 0.66 & 0.00 & 0.59 & 0.58 & 0.50 & 0.54 & 0.53 & 0.61 & 0.56 & 0.64 \\
\hline Chewiness (mJ) & 7.50 & 0.00 & 6.00 & 15.10 & 4.60 & 24.00 & 10.40 & 25.30 & 6.00 & 24.40 \\
\hline pH & 5.80 & 6.05 & 6.17 & 6.07 & 5.89 & 6.03 & 5.86 & 6.03 & 5.87 & 6.02 \\
\hline $\begin{array}{l}\text { TBA } \\
\text { (mg malonaldehyde/Kg sample) }\end{array}$ & 0.008 & 0.018 & 0.009 & 0.011 & 0.009 & 0.015 & 0.009 & 0.014 & 0.009 & 0.013 \\
\hline
\end{tabular}

Table 6 : Microbiological quality of beef burger samples during frozen storage at $-\mathbf{2 0}^{\circ} \mathrm{C}$ for 3 months

\begin{tabular}{|c|c|c|c|c|c|}
\hline \multirow{2}{*}{ Bacterial count $(\mathrm{CFU} / \mathrm{g})$} & \multirow[b]{2}{*}{ Type of burger } & \multicolumn{4}{|c|}{ Storage time at $-20^{\circ} \mathrm{C}($ month $)$} \\
\hline & & 0 & 1 & 2 & 3 \\
\hline \multirow[t]{5}{*}{ TVC } & $100 \%$ Meat & $6.0 \times 10^{4}$ & $3.9 \times 10^{3}$ & $4.2 \times 10^{3}$ & $3.8 \times 10^{3}$ \\
\hline & $20 \%$ Soybean concentrate & $5.3 \times 10^{4}$ & $4.7 \times 10^{3}$ & $3.8 \times 10^{3}$ & $4.1 \times 10^{3}$ \\
\hline & $10 \%$ Bulgur & $3.1 \times 10^{4}$ & $8.0 \times 10^{3}$ & $3.5 \times 10^{3}$ & $3.7 \times 10^{3}$ \\
\hline & $15 \%$ Bulgur & $3.5 \times 10^{4}$ & $5.1 \times 10^{3}$ & $4.6 \times 10^{3}$ & $3.5 \times 10^{3}$ \\
\hline & $20 \%$ Bulgur & $4.5 \times 10^{4}$ & $7.4 \times 10^{3}$ & $4.6 \times 10^{3}$ & $6.7 \times 10^{3}$ \\
\hline \multirow[t]{5}{*}{ Enterobacteriaceae } & $100 \%$ Meat & $5.1 \times 10^{3}$ & $2.0 \times 10^{2}$ & N.D & N.D \\
\hline & $20 \%$ Soybean concentrate & $7.2 \times 10^{2}$ & $4.0 \times 10^{2}$ & N.D & N.D \\
\hline & $10 \%$ Bulgur & $2.0 \times 10^{3}$ & $2.5 \times 10^{2}$ & N.D & N.D \\
\hline & $15 \%$ Bulgur & $2.4 \times 10^{3}$ & $2.0 \times 10^{2}$ & N.D & N.D \\
\hline & $20 \%$ Bulgur & $3.0 \times 10^{3}$ & $2.1 \times 10^{2}$ & N.D & N.D \\
\hline
\end{tabular}

E. coli, coliform and Staphylococcus aureus were not detected in all samples.

N.D: Not detected

range of TVC population did not exceed the critical limit of $5 \times 10^{6}$ referred by the relevant $95 / 2 \mathrm{EC}$ and 2073/2005 EC regulations for minced meat production, placing on market and meat preparation (EC, 1995 and EC 2005).

Enterobacteriaceae bacteria were only detected in very low load $\left(7.2 \times 10^{2}\right.$ to $\left.5.1 \times 10^{3} \mathrm{CFU} / \mathrm{g}\right)$ in different burger samples after preparation then not detected after one month of storage at $-20^{\circ} \mathrm{C}$. This may be due to the effect of freezing temperature. E.coli, Coliform and Staphylococcus aureus were not detected in all samples either before or after 3 months of frozen storage .
Sensory evaluation:- The data in Table (7) show that all roasted beef burger samples containing Bulgur flour (10-20\%) and /or soybean concentrate were judged as acceptable by the panelists. The beef burger product containing 10\% Bulgur flour had significantly $(P<0.05)$ the highest scores given by panalists for colour, taste, texture, odour and overall acceptability comparing with the other burger products. It was followed by burger containing 15\% Bulgur flour, 20\% Bulgur flour, 20\% soybean concentrate and $100 \%$ meat product. This means that the reduction in fat to $\sim 20 \%$ and protein to $\sim 63 \%$ and an increase in fiber to $8-12 \%$ in 
Table 7 : Sensory evaluation of roasted beef burger samples during frozen storage at $-200 \mathrm{C}$ for 3 months

\begin{tabular}{|c|c|c|c|c|c|c|}
\hline \multirow{2}{*}{ Property } & \multirow{2}{*}{ Type of burger } & \multicolumn{4}{|c|}{ Storage time at $-200 C($ month $)$} & \multirow[b]{2}{*}{ Mean } \\
\hline & & $\mathbf{0}$ & 1 & 2 & 3 & \\
\hline \multirow[t]{5}{*}{ 1- Colour } & $100 \%$ Meat & 7.9 & 7.8 & 7.5 & 6.0 & $7.30^{\mathrm{bc}}$ \\
\hline & $20 \%$ Soybean concentrate & 8.1 & 7.2 & 7.9 & 7.0 & $7.55^{\mathrm{ab}}$ \\
\hline & $10 \%$ Bulgur & 8.0 & 7.9 & 8.2 & 8.0 & $8.02^{\mathrm{a}}$ \\
\hline & $15 \%$ Bulgur & 8.3 & 7.9 & 8.1 & 7.0 & $7.82^{\mathrm{ab}}$ \\
\hline & $20 \%$ Bulger & 7.6 & 7.6 & 6.9 & 5.6 & $6.94^{c}$ \\
\hline Mean & & $7.98^{a}$ & $7.68^{a}$ & $7.72^{\mathrm{a}}$ & $6.72^{b}$ & \\
\hline \multirow[t]{5}{*}{ 2- Taste } & $100 \%$ Meat & 7.8 & 7.0 & 7.2 & 5.6 & $6.91^{b}$ \\
\hline & $20 \%$ Soybean concentrate & 7.6 & 6.3 & 6.8 & 6.0 & $6.67^{b}$ \\
\hline & $10 \%$ Bulgur & 7.8 & 8.1 & 6.7 & 7.0 & $7.40^{\mathrm{a}}$ \\
\hline & $15 \%$ Bulgur & 8.6 & 7.6 & 7.4 & 7.0 & $7.65^{\mathrm{a}}$ \\
\hline & $20 \%$ Bulgur & 7.4 & 6.6 & 6.4 & 6.6 & $6.76^{\mathrm{b}}$ \\
\hline Mean & & $7.84^{a}$ & $7.12^{b}$ & $6.90^{b}$ & $6.44^{c}$ & \\
\hline \multirow[t]{5}{*}{ 3- Odour } & $100 \%$ Meat & 8.0 & 7.5 & 7.7 & 6.0 & $7.31^{\mathrm{ab}}$ \\
\hline & $20 \%$ Soybean concentrate & 7.5 & 7.0 & 7.1 & 5.0 & $6.90^{\mathrm{b}}$ \\
\hline & $10 \%$ Bulgur & 7.9 & 8.0 & 7.8 & 7.3 & $7.75^{\mathrm{a}}$ \\
\hline & $15 \%$ Bulgur & 8.3 & 7.9 & 7.8 & 6.6 & $7.66^{\mathrm{a}}$ \\
\hline & $20 \%$ Bulgur & 7.6 & 7.5 & 7.1 & 5.6 & $6.98^{b}$ \\
\hline Mean & & $7.86^{\mathrm{a}}$ & $7.58^{\mathrm{a}}$ & $7.52^{\mathrm{a}}$ & $6.10^{b}$ & \\
\hline \multirow[t]{5}{*}{ 4- Texture } & $100 \%$ Meat & 7.0 & 6.7 & 6.2 & 5.6 & $6.39^{c}$ \\
\hline & $20 \%$ Soybean concentrate & 7.8 & 7.3 & 7.5 & 5.6 & $7.06^{b}$ \\
\hline & $10 \%$ Bulgur & 7.9 & 8.1 & 7.8 & 7.0 & $7.70^{\mathrm{a}}$ \\
\hline & $15 \%$ Bulgur & 8.3 & 7.6 & 8.2 & 7.0 & $7.75^{\mathrm{a}}$ \\
\hline & $20 \%$ Bulgur & 7.9 & 7.6 & 7.1 & 6.0 & $7.75^{\mathrm{a}}$ \\
\hline Mean & & $7.78^{a}$ & $7.46^{\mathrm{a}}$ & $7.34^{a}$ & $6.24^{b}$ & \\
\hline \multirow{5}{*}{$\begin{array}{l}\text { 5- Overall ac- } \\
\text { ceptability }\end{array}$} & $100 \%$ Meat & 7.2 & 7.1 & 6.3 & 5.8 & $6.60^{\mathrm{b}}$ \\
\hline & $20 \%$ Soybean concentrate & 7.5 & 6.8 & 7.1 & 6.6 & $6.91^{\mathrm{b}}$ \\
\hline & $10 \%$ Bulgur & 8.5 & 8.0 & 7.8 & 6.3 & $7.55^{\mathrm{a}}$ \\
\hline & $15 \%$ Bulgur & 8.1 & 7.7 & 8.0 & 6.3 & $7.65^{\mathrm{a}}$ \\
\hline & $20 \%$ Bulgur & 7.8 & 7.4 & 7.0 & 5.6 & $6.98^{b}$ \\
\hline Mean & & $7.83^{a}$ & $7.33^{\mathrm{b}}$ & $7.24^{b}$ & $6.12^{c}$ & \\
\hline
\end{tabular}

Means with the same letter are insignificantly different at $P<0.05$ level.

burger formulation can produce acceptable product. Also, the panelists observed changes in colour, texture and odour of different beef burgers after 3 months of frozen storage at $-20^{\circ} \mathrm{C}$.

\section{CONCLUSION}

Replacing soybean concentrate with Bulgur flour did not affect quality and storage stability of beef burger. No differences were detected between their sensory evaluation, $\mathrm{pH}$, TBA and microbiological quality before and after frozen storage at $-20^{\circ} \mathrm{C}$ for 3 months.

\section{ACKNOWLEDGEMENT}

The authors are thankful to Prof. Dr. Yehia Gamal EL- Din Moharram, Prof. of Food Science and Technology, Faculty of Agric., El-Shatby, Alex. University for his support and valuable help to carry out the manuscript.

\section{REFERENCES}

Aman, M.B. 1983. Effect of cooking and preservation methods on the water holding capacity (WHC) of Mullet fish in relation with changes occurred in muscle proteins. Zeitschrift fur 
Lebensmittel-Untersuchung und - Forschung, 177: 345-347.

AOAC. 1990. Official Methods of Analysis. 15 th ed. Association of Official Analytical Chemist, Washington, DC. USA.

AOAC.2000. Official Methods of Analysis.17th ed. Association of Official Analytical Chemists, Gaithersburgh. Maryland, USA.

Bayram, M.2007. Application of Bulgur technology to food aid programs. Cereal Food World, 52: 249-256.

Bethesda, M.D.1986. Physiological effect and health consequences of dietary fiber. Life Science Research office. Federation of American Societies for Experimental Biology USA. Pich ,Susan M.center for Food safety and Nutrition.

Borderias, A.J., Sanchez-Alonso, I. \& Perez-Mateos, M. 2005. New applications of fibers in foods: Addition to fishery products. Trends in Food Science and Technology, 16: 458-465.

Brand-Williams, W., Cuvelier, M.E. \&Berset, C.1995. Use of free radical method to evaluate antioxidant activity. Lebensmittel Wissenchaft und- Technologie, 28: 25-30.

Cai, y., Sun, M., Xing, J. Luo, Q. \& Corke, H. 2006. Structure- radical scavenging activity relationships of phenolic compounds from traditional Chinese medicinal plants. Life Sciences, 78: 2872-2888.

Chau, C.F. \& Cheung, P.C.K. 1998. Functional properties of flours prepared from three Chinese indigenous legume seeds. Food Chemistry, 61: 429-433.

Del-Rosario, R.R. \& Flores, D.M. 1981.Functional properties of four types of mung bean flour. Journal of the Science of Food and Agriculture, 32: 175-180.

E.C.1995. European parliament and council directive No 95/2 EC of 20 February 1995 on Food additives other than colours and sweeteners. Official Journal of European Union, L 61 pp. $1-53$.

E.C. 2005. Commission Regulation (EC) No 2073/ 2005 of 15 November, 2005. On microbiological criteria for foodstuff. Official Journal of the European Union, L338.pp.1-26.

El- Magoli, S.S., Laroia, S. \& Hasen,P. 1996. Flavor and texture characteristics of low fat ground beef patties formulated with whey protein concentration. Meat Science, 42: 179-193.

Franke, A.A., Custer, L.J., Cerna, C.M. \&Narala, K.K. 1994. Quantitation of phytoestrogens in legumes by HPLC. Journal of Agricultural and Food Chemistry, 42: 1905-1913.

Giambanelli, E., Ferioli. F. \& D’Antuono, L.F. 2018. Retention of alkyl resorcinols antioxidant activity and fatty acids following traditional hulled wheat processing. Journal of Cereal Science, 79: 98-105.

Gupta, S. \& Savalia, C.V. 2012. Application of biotechnology in improving livestock products. Veterinary World, 5: 634-638.

Hayes, J.E., Stepanyan, V. Allen, P.O., Grady, M.N. \& Kerry, J.P. 2009. Effect of leutein, sesamol, ellagic acid and olive leaf extract on the quality and shelf-life stability of packaged raw minced beef patties. Meat Science, 84. 613-620.

Hendrich, S., Lee, K.W., Xu,X., Wang, H.J. \& Murphy, P.A. 1994. Defining food components as new nutrients. The Journal of Nutrition, 124:1789S-1792S.

Hue, S.M. Boyce, A.N. \&Somasundram, C. 2011. Antioxidant activity, phenolic and flavonoid contents in the leaves of different varieties of sweet potato (Ipomoea batatas). Australian Journal of crop Science, 6:375-380.

International Commission on Microbiological Specification for Food (ICMSF). 1978. Microorganisms in Food 4:Application of Hazard Analysis Critical Control Point (HACCP), System to Ensure Microbilogical Safety and Quality. Black Well Scientific Publication Oxford, London, U.K.

Köksel, H., Edneyt, M.J. \& Özkayat,B. 1999. Barley Bulgur: effect of processing and cooking on chemical composition. Journal of Cereal Science, 29: 185-190.

Kumar, P., Kumar, S., Tripathi, M.K., Mehta, N., Ranjan, R., Bhat, Z.F. \& Singh, P.K. 2013. Flavonoids in the development of functional meat products: A review. Veterinary World, 6: 573-578.

Malika, N.E., Prabhakar, K. \& Reddy, P.M. 2009. Low fat meat products. An Overview. Veterinary World, 2: 364-366.

McDonagh, C.,Troy, D., Desmond, E. \& McDemott, H. 2005. Nutritional enhancement of 
meat products with dietary fibers. Project RMIS. No. 4957. The National Food Centre, Ashtown, Dubin 15.

Meilgaard, M., Civille, G.V. \& Carr, B.T. 1999. Sensory evaluation techniques. $3^{\text {th }}$ ed. Boca Raton: CRC. pp. 8-12.

National Cancer Institute. 1984. Diet, Nutrition and Cancer Prevention: A guide to Food Choices. US Department of Health and Human Services, National Institutes of Health. NIH Publication No. 85 - 2711.P.8.

Okerman, H.W. 1976. Quality control of post-mortem muscle tissue. Columbus, USA, Department of Animal Science. Ohi State University.

Oxoid.2002. Tryptone bill X- glucronide medium (TBX); A selective chromogenic media for the detection and enumeration of E.coli in food. http: // www oxoid- com./ UK/ index. asp? mpage $=$ ipreductetail $\&$ pre $=\mathrm{Cm}$ 0945\& 1= EN \&x.

Ozvural. H. \&Vural, H.2008. Utilization of interesterified oil blend in the production of frankfurters. Meat Science,78: 211-216.

Park, S.Y., Yoo, S.S., Hu, J., Euv, J.B., Lee, H.C., Kin,Y.J. \& Chin, K.B.2007.Evaluation of lipid oxidation and oxidative products as affected by pork meat cut packaging method and storage time during frozen storage $\left(-10^{\circ} \mathrm{C}\right)$. Journal of Food Science,72: 114119.

Perumalla. A.V., Navam,S. \&Hettiarachchy, S. 2011. Green tea and grape seed extracts. Potential Applications in Food Safety and Quality. Food Research International, 44: 827833.

Pintado, T., Herrero,A.M., Jimenez-Colmenero, F. \& Ruiz-Capillas, C. 2016. Strategies for incorporation of chia (Saliva hispanical L) in frankfurter as a health-promoting ingredient. Meat Science, 114: 73-78.

Pratt, D.E. \& Birac, P.M. 1979. Source of antioxidant of soybeans and soy products. Journal of Food Science, 44: 1720-1722.
Ruban, S. W., Kalaikannan. A. \& Rao, V.A. 2009. Physico. chemical characteristics of pork sausage during refrigerated storage. Veterinary World, 2: 95-97.

Sandhar, H.K., Kumar, B., Tiwari, P., Salhan, M. \& Sharma, P. 2011. A review of phytochemistry and pharmacology of flavonoids. International pharmaceutica sciencia, 1: 25-41.

Santipanichwing, R. \& Suphantharika, M.2007. Carotenoids as colorants in reduced-fat mayonnaise containing spent brewer's yeast $\beta$ - glucan as a fat replacer. Food Hydrocolloids, 21: 565-574.

Tapas, A.R., Sakarkar, D.M. \&Kakde, R.B. 2008. Flavonoids as nutraceuticals: A review. Tropical Journal of Pharmaceutical Research, 7: 1089-1099.

United States Department of Agriculture. 2011. USDA Database for the flavonoid content of selected foods. Edt. Bhagwat, S., Haytowitz, D. B. and Holds, J.M. Nutrient Data Laboratory, West Maryland, USA.

Wang, H.J. \& Murphy, P. A. 1994. Isoflavone content in commercial soybean foods. Journal of Agriculture. Food Chemistry, 42: 1666-1673.

Wells, A.F. \& Ershoff. B.H. 1961. Beneficial effects of pectin in prevention of hypercholesterolemia and increase in liver cholesterol in cholesterol fed rats. Journal of Nutrition, 74: 87-92.

Wijngaard, H.H. \& Arendt, E.K. 2006. Buckwheat. Cereal Chemistry, 83: 391-401.

Yang, N.L., Zhang, K., Jiao. R., Ma, K.Y., Zhang, R. \& Chen,Z.Y. 2014. Hypocholesterolemic activity of buckwheat flour is mediated by increasing sterol excretion and down-regulation of intestinal NPCIL and ACATZ. Journal of Functional Foods, 6: 311-318.

Yuan, S. \& Chang, S.K.C. 2007. Texture profile of tofu as affected by instron parameters, sample preparation and correlation of instron hardness and springiness with sensory scores. Journal of Food Science, 72: 136-145. 


\section{تأثير إحلال مركز فول الصويا بلدقيق البرغل علي جودة والثبات التخزيني لبرجر التلحم البقري البري}

نادية أحمد عبد العزيز'، أمل محمد عبد الرازقَ ، فاتن فاروق عبد السلام ا - قسم بحوث تكنولوجيا اللحوم والاسماك - معهد بحوث تكنولوجيا الاغذية - مركزالبحوث الزراعية -الاسكندرية -مصر •

\section{r- قسه علوم وتقنية الأغذية -كلية الزراعة )الشاطبى) - جامعة الإسكندرية}

تم دراسة إحلال مركز فول الصويا بدقيق البرغل فى صناعة برجر اللحم البقري وأوضحت النتائج أن البرغل

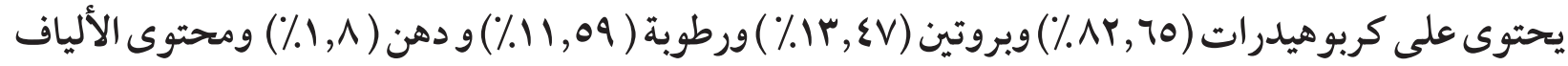

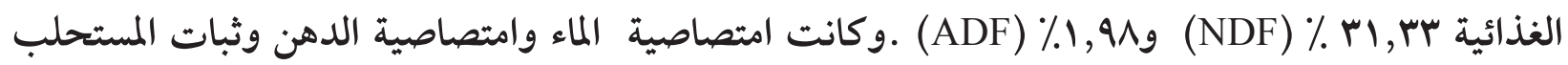

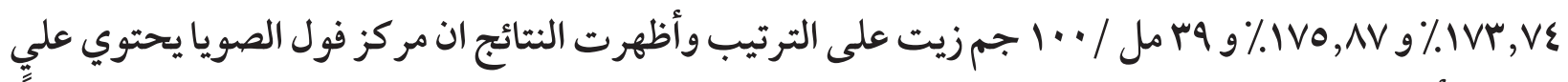

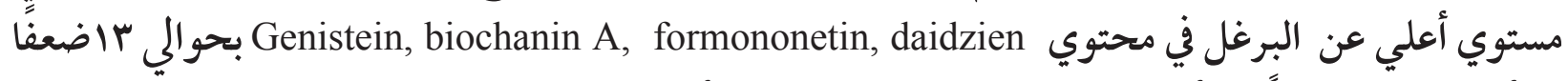

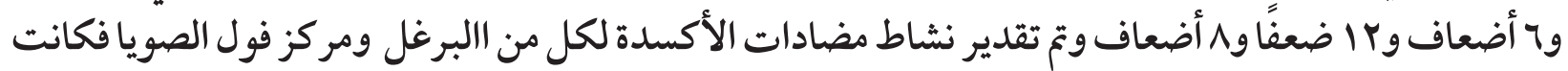

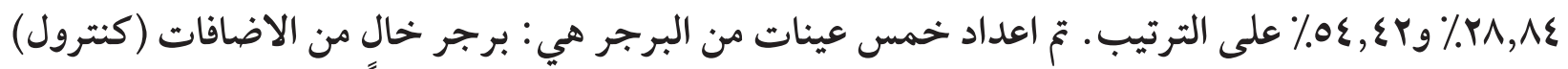

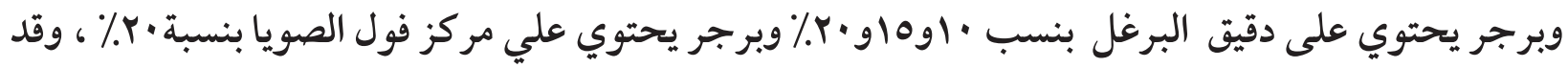

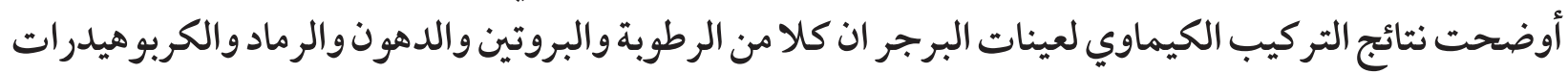

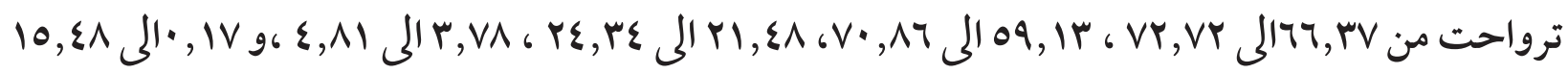

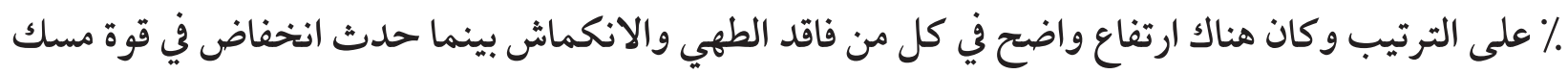

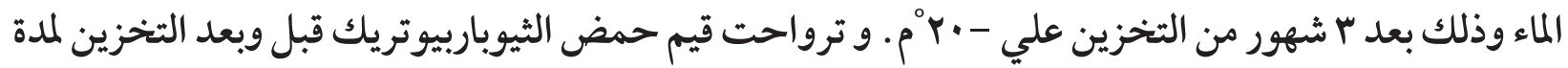

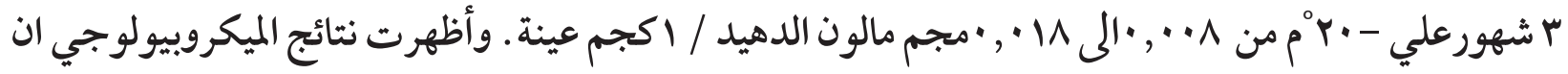

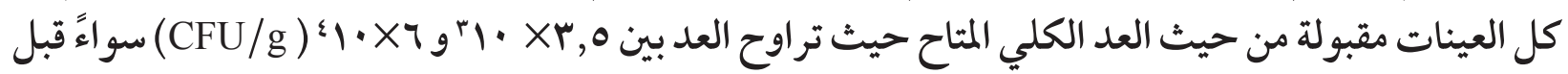

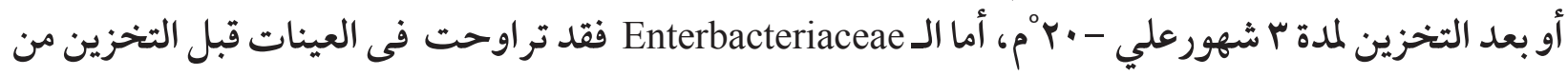

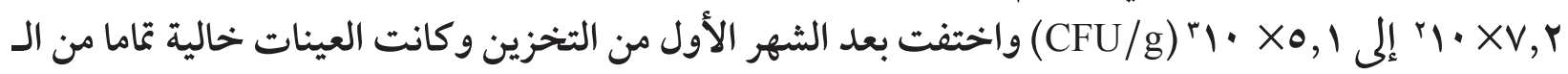

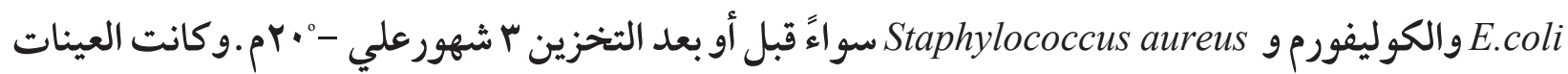

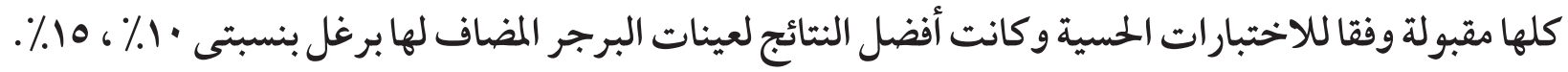

